\title{
Multi-level governance and social cohesion in the European Union: the assessment of local agents, a study case inside Galicia
}

Governança multinível e coesão social na União Europeia: a valoração dos agentes locais, um estudo de caso dentro da Galícia

http://dx.doi.org/10.1590/0034-7329201400311

MÓNICA LÓPEZ-VISO*

ANTÓN LOIS FERNÁNDEZ ÁLVAREZ**

Rev. Bras. Polít. Int. 57 (2): 196-213 [2014]

Introduction

The European Social Fund (ESF) together with other Structural Funds (SF), of which the Autonomous Community of Galicia (Spain) has been a major recipient, constitutes the key components of EU cohesion policy. Though the SF has become the most tangible expression of EU policy for many EU and Galician citizens, this does not imply that policy rationale or the criteria for the implementation of these resources is readily understood by citizens primarily due to the complexity and overwhelming number of directives, regulations, provisions, and procedures established for policy implementation.

The literature concerning SF has focused primarily on macroeconomic models designed to assess its role and impact in promoting 'multi-level governance' in the European Union (Bache 2007; Hooghe and Marks 2001). In comparison, few studies on ESF have examined the role and influence of subnational entities in the decision-making process for allocating these resources or the perception of local public and private actors regarding policy goals and implementation. An innovative approach has emphasized the role of 'micro' rather than 'macro' mechanisms in evaluating the impact of ESF on domestic activation policies in the three Belgian regions: Flanders, Wallonia and Brussels (Verschraegen et al. 2011).

* University of Vigo, Vigo, Galicia, Spain (mviso@uvigo.es).

** University of Vigo, Vigo, Galicia, Spain (alfa@uvigo.es). 
In Spain, few studies have focused on the implementation of SF programmes, and several authors using an array of methodologies have positively appraised the outcomes and overall impact of SF on fundamental macroeconomic parameters of the Autonomous Communities in Spain (Sosvilla-Rivero and Hercé 2004), and in particular the Autonomous Community of Galicia (Nogueira 2008; Espasa 2008). Notwithstanding, other studies have suggested positive macroeconomic outcomes should be interpreted with caution since the disparity between regions has grown over the last two decades (Rodriguez and Fratesi 2004), and certain factors may prove to be counterproductive or undermine the efficacy of SF such as the 'dislocation of industry', the risks associated to excessive regional specialization characteristic of less developed regions, and flawed design and implementation of development strategies (Fayolle and Lecuyer 2000; Armesto 2008).

The aims of this study were to assess the local implementation of ESF by exploring the characteristics and obstacles that hinder the participation of local agents in multilevel governance, and to evaluate the achievements and shortcomings of the local implementation of ESF as perceived by those who implement policy on the ground.

The initial hypothesis of this study was that the implementation of ESF was based on the principle of shared management i.e., ESF lines of action are drawn up at a European level, but the actual execution on the ground is the responsibility of the national, regional, and local authorities of each member state. Hence, it was assumed that local agents played a key role due to their territorial proximity and shared social reality with the target population. Bearing in mind these assumptions, this study explored if the participation of local agents in the management of ESF had been reinforced during past programming periods as endorsed by the new analytical approach of European multilevel governance, and analyzed the degree to which the local actors involved in the final phase of implementation shared this perception, and the subsequent implications for the operationalization of ESF.

\section{Rationale and analytical framework}

Case study methodology was deemed to be appropriate for approaching the issues and circumstances under study. The method applied in this study is grounded on an approach based on the personal evaluation of the actors involved in implementing funding on the ground. This methodological approach has been successfully employed in local case studies (Leiber 2005; Fotea et al. 2011), and has proven to be a useful methodological tool for exploring the patterns of interaction between groups of actors involved in implementing ESF (Laffan 1983).

The findings of this study contribute to the literature in several ways. First, in proportional terms, Spain is the country that has been the primary beneficiary of EU funds (González and Benedicto 2006), and Galicia is a major recipient of SF, in particularly ESF. Galicia is according to current EU terminology a NUTS II 
region with four NUTS III regions corresponding to the four provinces of Galicia i.e., La Coruña, Lugo, Ourense, and Pontevedra. Since Spain's integration in the European Economic Community in 1986, Galicia has received an estimated 18 billion Euros in SF, which have been invested in the economic development of the region. Thus, Galicia is only second to Andalusia in the ranking of Autonomous Communities in Spain receiving SF. As for ESF, Galicia received 936,1 million euros during the 2007-2013 programming period (Xunta De Galicia 2008c).

Second, in terms of the framework of multilevel governance, Galicia is part of a decentralized state. The Spanish Statute of Autonomy approved in 1981 set up the Autonomous Government of Galicia, and only five years later Spain became a member of the EU coinciding with the Single European Act that introduced the socioeconomic cohesion policies of SF. Thus, the regions began to be conceived from a European perspective as "instruments indispensables à l'aménagement du territoire communautaire" (Deyon 1997). Simultaneously, the Autonomous Communities in Spain have gradually acquired an increasing number of competencies in areas such as health, education, employment, and so forth. Spain has forged its own unique model, somewhat federal in nature, with three tiers of government: national, regional autonomies, and local authorities who have the statutory autonomy to manage their own affairs. This scenario of political and administrative decentralization should in theory foster the emergence of partnerships between the different tiers of administration in the management of ESF, but in practice local agents in multilevel governance expressed their reservations regarding their participation (Petit 2010).

Third, this study focused on the Province of Ourense in Galicia given that it was the territorial region to which our academic institution belongs and it would enable us to assess on-ground conditions and explore first-hand an array of parameters/dimensions of the local political and institutional context where ESF implementation actually unfolds. In recent years, the participation of local authorities and government in the management of ESF has gradually increased by acquiring competencies on employment policy i.e., the main allocation of ESF. This process, which has been recently documented by Sánchez (2013), has been further reinforced in recent years by both European institutions and local authorities who seek to promote local employment strategies (Le Galès 2003) on the grounds that the involvement of local actors maximizes the efficacy and equity of public policies (Stoker 2000; Kooiman 2003), and responds to the crisis in the legitimacy of representative democracy (Pharr and Putnam 2000; Mouffe 2003).

It is worth noting that a unique political style of local management has emerged in this region of Spain derived from the interlocking networks of clientelism that influence political decision-making and the allocation of local economic resources (Máiz 1994). Clientelism has become structural with its own idiosyncratic character both in Galicia and Ourense, which undermines the 
fundamental aim of ESF (López 2004, 171). Other authors have even defined the development of local agents in Galicia as 'funded clientelism', and claim Local Development Agencies have become the instruments for allocating the financial resources of SF (Calvo and Lerma 2008).

\section{The management of European Social Funds: joint management, fundaments and autonomous planning}

Economic and social cohesion is the guiding principle of ESF and other SF that aim to achieve a series of collective objectives, and to facilitate the territorial allocation of resources by giving priority to the most disadvantaged regions whose development is lagging behind. According to this principle, the structural actions receiving funding are designated at European level, but implementation on the ground is the responsibility of national or regional authorities of each member state.

The main priority for the joint management of ESF is to promote employment and vocational training programmes and services. In Spain, employment and vocational training is co-financed by the ESF, regulated by central government and by each autonomous government, and applied on the ground by local or supralocal public and private entities: provincial councils, local councils municipal associations, social organizations, and not-for-profit organizations. This is line with the process of Europeanization of public administration, the decentralization of member states, and the territorialization of European policies that apply not only to employment policies but also to a wide range of socioeconomic policies.

\section{Joint Management of the Funds and Multi-level Governance}

Since the 1980s the so-called bottom-up procedure consisting of 'the everyday internationalization that grows from the bottom, based on specific relations between men' (Censis 1991, 22), is gradually becoming established in the economic development of the regions and cities, a phenomenon that has been described by several authors as the 'Europe of the regions' (Keating and Jones 1985; Keating 2008), which refers to the emergence of dense networks of regional and global relations operating free from the regulations and restrictions of state control (Held 1995; Rhodes 1997).

Currently, governance in the European Union is characterized by EU policies being negotiated by transnational, national, regional, and local institutions i.e., a process that has been termed 'multi-level governance' (Bulmer 1994) that is progressively transforming the Commission into a fully-fledged 'organizationalnetwork' (Metcalfe 1995). The emergence of the multi-level governance model according to Marks et al. (1996) is the result of an extensive process of institutional decisional reallocation or delegating authority both upward (the Union) and 
downward (regions and local entities). The SF has facilitated the creation of a network of public and private regional actors that enhances the participation of local and regional agents in European social cohesion policies (Smith 1997; Batterbury 2002; Ferry and McMaster 2005). In addition, Europeanization has further activated the participation of local and regional agents (Fargion et al. 2006; Morata 2007). As Ordóñez (2011) has pointed out, in a 27-member Union the current model for the decentralized management of SF is proving to be the only viable option.

Though the vast majority of studies on local governance have focused on this model of decentralized management (Stoker 1998), the greater role of subnational entities within the European Union does not imply that multi-level governance of the regions is steadily replacing the nation-state. Empirical research in political science has underscored this process does not entail the loss of state control but rather a change in form (Mayntz 1998), or in the words of Kooiman (2003) it is more appropriate to speak of changing roles of government than diminishing ones i.e., the mere fact that governments have to cooperate with other social actors does not in any way make governmental intervention irrelevant or obsolete.

National authorities, and in particular public administration, together with the Commission are responsible for co-financing and managing EU funded projects (Bache and Jones 2000). Thus, national administrations play a crucial role in implementing EU policies. Though joint management has boosted the role of subnational authorities in local community structures, the role of subnational governments in structural policy is often overrated (Closa 2004, 99).

\section{ESF: priorities and lines of action}

The policies of the ESF have been put into practice from the very out-start of European integration. The ESF was initially created from the SF in 1957, and without a doubt it has been the single most significant social financial instrument of the European Union. The ESF was conceived as a fundamental mechanism for achieving economic, social and territorial cohesion through the promotion of employment and training policies. Similar to the SF, the ESF is based on a number of principles e.g., joint management, programming, additionality, and co-financing. In other words, financial support from the EU always runs parallel to national public or private funding.

Recent studies have highlighted that in the past decade the ESF has had a catalyzing effect on the innovation of activation instruments as well as on the design and management of employment policies. Indeed, the ESF has been increasingly linked to the European Employment Strategy (EES) since 2000, particularly in terms of its local application in 2009 (López-Santana 2009). Both the ESF and the EES have contributed to reducing discrimination at work by mutually 
reinforcing integrated strategies. The coupling of EES policy objectives with the financial resources of the ESF has boosted and strengthened the management of employment policies throughout Europe (Vanhercke et al. 2011, 754).

The programming of the ESF in Galicia: collaboration and shortcomings

The Autonomous Community of Galicia is a priority region for structural funding as it has been classified as 'Objective 1' i.e., a 'convergence' region classified by the EU as a less developed region. Several weaknesses have been identified in the Autonomous Community of Galicia such as the dispersion and ageing of the population ${ }^{1}$, the poor development of ICT infrastructure, the inability of the private sector to absorb skilled labor, the rate of school failures with youngsters leaving compulsory education without any qualifications, territorial disequilibrium between coastal and inland areas, and gender inequality (Xunta De Galicia 2007, 37).

Currently, the programming periods begin with the design of a series of documents, the first of which is the National Reform Programme that is the main instrument for channeling in each member state the actions for achieving the objectives outlined in the Lisbon strategy, which in turn is directly linked to the National Strategic Reference Framework (NSRF) that ensures the coherence of funding programmes. These documents are drafted in close collaboration with the Commission and in partnership with all the actors involved.

In the 2007-2013 programming period ${ }^{2}$, the ESF in Galicia was part of the Strategic Framework for Economic Convergence of Galicia (MECEGA) that sets out the strategy for SF intervention, which is equivalent to the 2007-2013 NSRF at national level for the whole of the Spanish territory (Xunta De Galicia 2008b and 2008c). According to this plan two Operational Programmes (OP)_ERDF and the $\mathrm{ESF}^{3}$ - were designed for Galicia. Unlike the previous programming periods, each programme consisted of a single-fund (Xunta De Galicia 2008a, 22), though both of the programmes were closely connected with the joint strategy outlined in the MECEGA (Xunta De Galicia 2008a, 229) (see Figure 1).

1 The province of Ourense has a population of 326,724 inhabitants living in over 8,000 population centers. Though most of the population lives in the capital and other major cities, more than 2,000 rural population centers have fewer than a dozen inhabitants, and 250 rural population centers have been abandoned (Instituto Nacional de Estadística, 2013).

2 In the financial agreement for 2007-13, Spain was allocated a SF budget of $€ 35$ billion, of which $€ 8$ billion correspond to ESF. Though this entailed a 40 per cent reduction as compared to the previous programming period, the fall in Galicia was only 9 per cent (López 2010).

3 Galicia received ESF funding through the Regional OP (€358.5 million), and the three Multi-Regional OP: 'Adaptability and Employment' (€542.5 million), 'Fight against discrimination' ( $€ 30.8$ million), and 'Technical Assistance' (€4 million) (Xunta de Galicia 2008a). 


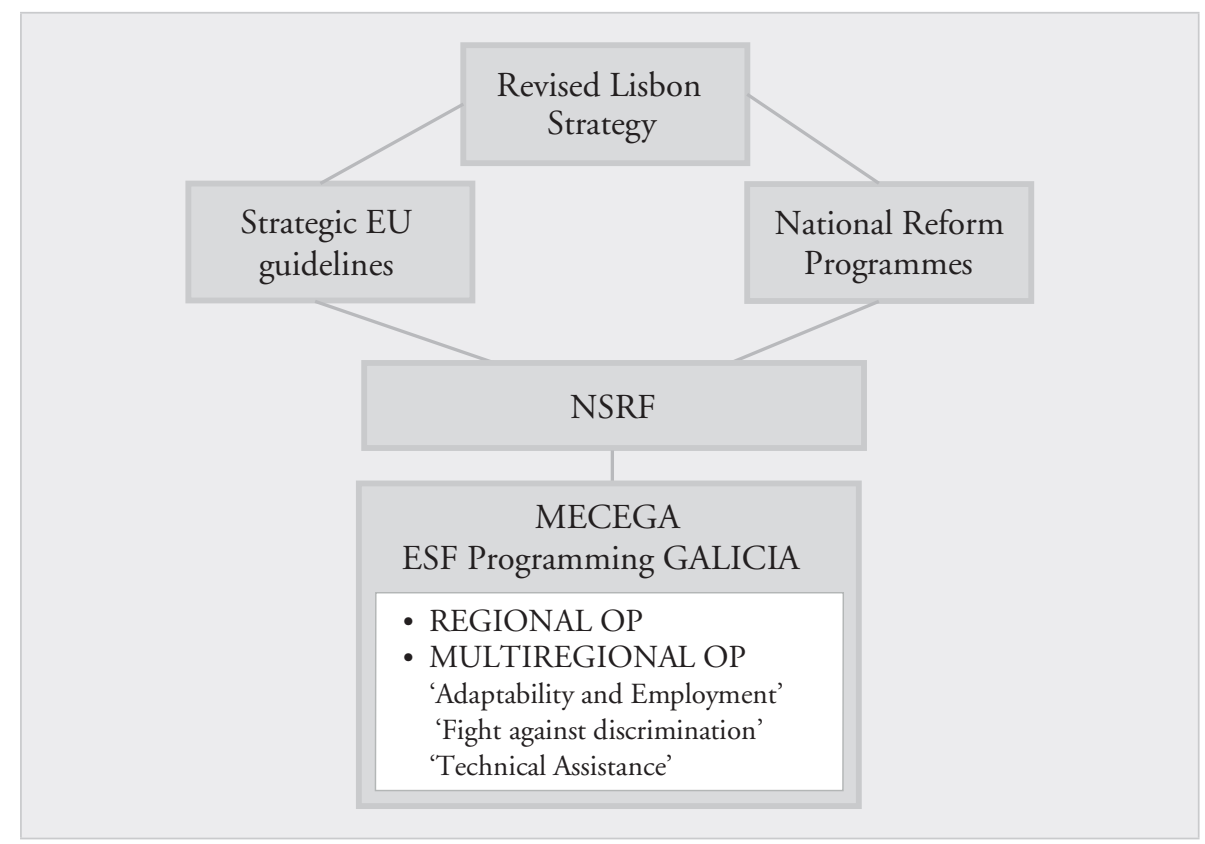

Figure 1. ESF Programming in Galicia 2007-2013 according to national and EU policy.

One of the most frequently reported drawbacks regarding ESF, which was corroborated by the present study on ESF management in Galicia, refers to the complexity of the system and the excessive bureaucratic process (Quasar 2003). The renewed procedures underscored the Commission's greater trust and confidence in the planning abilities of member states, where the regions have adopted innovative roles that entail fresh challenges and transformations (Tömmel 2004).

In recent years, the management of ESF by the Spanish central government has been significantly constrained and delegated to regional public administration. It was not until the beginning of the nineties that this competence was handed down to the autonomous communities in Spain. The current organizational structure of the Autonomous Government of Galicia illustrates well the new ties with the Union European, particularly in relation to the management of the ESF i.e., it is not only responsible for funding, but also provides regulations, norms and standards as well as a legal framework for implementing policy. Since 1998 the Autonomous Government of Galicia has been empowered with competences in industry, employment and vocational training. Thus, the Xunta de Galicia is responsible for managing and supervising employment and vocational training programmes, and to settle labor disputes. Whereas the management of these policies was almost the exclusive domain of central government during the first years of ESF implementation in Galicia, but the role of the Autonomous Government 
of Galicia during successive programming periods has steadily increased from managing 9 per cent of resources in the first years to the current 38 per cent of funding (López 2010).

However, the empowering of regional administration has not been matched by a similar devolution of power to local authorities whose participation in regional development plans is restricted to accessing a few initiatives of the Regional Operational Programme. Thus, the local actions undertaken by councils that are sensitive to the demands of their citizens become isolated projects that do not pursue a common goal regardless as to whether the projects are included or not in an operational programme (Pardo 2000) (see Table 1).

Table 1. Institutional organizational chart of the Galicia Regional Operational Programme ESF 2007-2013.

\begin{tabular}{|c|c|c|}
\hline Function & Task & Agency \\
\hline $\begin{array}{l}\text { Managing } \\
\text { Authority }\end{array}$ & $\begin{array}{l}\text { PO management and } \\
\text { implementation. Guarantees } \\
\text { the appropriate use of the ESF. }\end{array}$ & $\begin{array}{l}\text { Unidad de Gestión de la Unidad } \\
\text { Administradora del FSE (Ministerio de } \\
\text { Empleo y Seguridad Social -MESS-). }\end{array}$ \\
\hline $\begin{array}{l}\text { Certifying } \\
\text { Authority }\end{array}$ & $\begin{array}{l}\text { Certifying expenses and } \\
\text { supervising payment to } \\
\text { beneficiaries. }\end{array}$ & $\begin{array}{l}\text { Unidad de Certificación de la Unidad } \\
\text { Administradora del FSE (MESS). }\end{array}$ \\
\hline $\begin{array}{l}\text { Audit } \\
\text { Authority }\end{array}$ & $\begin{array}{l}\text { Legal-financial supervision } \\
\text { of funds }\end{array}$ & $\begin{array}{l}\text { Intervención General de la Xunta de } \\
\text { Galicia, integrada con la Intervención } \\
\text { General de la Administration estatal. }\end{array}$ \\
\hline $\begin{array}{l}\text { Intermediate } \\
\text { Bodies }\end{array}$ & $\begin{array}{l}\text { Coordination, counselling, and } \\
\text { evaluation of the implementing } \\
\text { agencies. Mediation between } \\
\text { agencies and the supervising } \\
\text { authority. }\end{array}$ & $\begin{array}{l}\text { Dirección General de Proyectos y } \\
\text { Fondos Europeos (Xunta de Galicia). }\end{array}$ \\
\hline $\begin{array}{l}\text { Implementing } \\
\text { agencies and } \\
\text { managers } \\
\text { (beneficiaries) }\end{array}$ & $\begin{array}{l}\text { Project coordination, design, } \\
\text { presentation, financing, and } \\
\text { implementation. Responsible } \\
\text { for project justification, legality, } \\
\text { and implementation. }\end{array}$ & $\begin{array}{l}\text { Provincial councils, commonwealths } \\
\text { of municipalities, local councils and } \\
\text { other agencies }\end{array}$ \\
\hline $\begin{array}{l}\text { Final } \\
\text { Beneficiaries } \\
\text { or recipients }\end{array}$ & Final Beneficiaries & $\begin{array}{l}\text { Businesses and workers from specific } \\
\text { sectors, unemployed, women, } \\
\text { youngsters, immigrants, impaired, } \\
\text { people at risk of being excluded from } \\
\text { work, not-for-profit organizations, } \\
\text { associations, etc. }\end{array}$ \\
\hline
\end{tabular}

Source: Data was gathered from the Programa Operativo Fondo Social Europeo de Galicia 2007-2013 (Xunta de Galicia, 2008a); and the Informe anual 2011. Programa Operativo Regional de Galicia (Xunta de Galicia, 2012). 
The current regulations stress the need for local participation to promote the good-governance of ESF (European Parliament 2006), and a number of official reports have underscored the crucial role performed by local agents, and other social actors (European Parliament 2014). However, local authorities have been virtually ignored in the management of funding, and even more so in its distribution. In fact, local initiatives are practically reduced to the dictates of the central government and the autonomous communities (Ordóñez 2011).

\section{Results}

The results of this study concerning how local actors perceive and assess the instruments for the 'creation of Europe' have corroborated the findings reported in the literature concerning the motivation, functioning, and shortcomings underlying the local implementation of ESF. In terms of methodology, the micro-level qualitative design employed in this study consisted of undertaking semi-structured interviews of the local public and private entities involved in implementing the ESF in the Province of Ourense. The data was obtained from 27 in-depth interviews using a semi-structured questionnaire that was administered to specialist informants such as managers and technical experts from provincial councils, councils, municipal associations, social organizations, and not-for-profit organisations (see Appendix I for further details of the sample), who were responsible for implementing ESF funded programmes in a wide range of sectors.

The local actors who had participated in the management or implementation of structural policies during the 2007-2013 programming period were either managers of grants for employment, fund managers, auditors or managers of project applications. A third of the sample were the potential beneficiaries of funding, the second largest group were professionals with an institutional role in OP design, and a smaller number were experts in the consultation stage.

The questionnaire was focused on the last two ESF programming periods, and the interviews were undertaken from 2010 to 2012. The data obtained from the interviews was supplemented by several primary sources of European, national, and subnational official documents: studies, plans, Annual Reports, Operational Programmes, Evaluations, and Communication Reports or Plans of ESF.

This study highlighted that it is widely acknowledged that participating in a system of pluriannual programming in line with European directives enhanced the efficacy of subnational tiers of administration even though planning became more complex. Moreover, this study has shown that the ESF was positively rated in contributing to generating and innovating active employment policies. Notwithstanding, there was an overall feeling of unfulfilled expectations in terms of the outcomes of ESF funding and the lack of participation of local entities. 


\section{Local participation in European policies: the Europeanization of public administration and attitudes}

The increasing participation of local authorities has been endorsed by European institutions for political and economic reasons given that regionalization and administrative decentralization are considered to be crucial for democratic stability. The efficient use of funding and the success of regional policies depend to a large extent on the involvement of all the stakeholders (Xunta De Galicia 2008d). Collaboration must go beyond mere consultation, and must seek the active participation of all the stakeholders involved in each development and implementation phases of political cohesion (Consejo Económico y Social 2013).

In the 2007-2013 programming period, the ESF in Galicia was part of the MECEGA that redirected the economic policy of the Autonomous Government of Galicia towards the European priorities enshrined in the Lisbon Strategy. Furthermore, EU directives required a Strategic Programme i.e., the NSFR that served as an 'umbrella' for both Regional and Multi-Regional OPs. The implementation of EU policy has been conducive to the progressive Europeanization of public administration including subnational administration (Morata 2007). The implementation of ESF in particular has contributed to the convergence of Galician public administration towards a common model based on EU guidelines and standards of best practice.

Thus, according to one respondent, the ESF had "contributed to a change in business mentality" (Interview 2 and 5), which corroborated the changes observed by Verschraegen who described how the ESF 'had functioned as a driver of policy shifts by helping to implement new policy concepts', and how 'a by-product of this dynamic is the maturation of a European state of mind' (2011, 62).

The drawback is that the management of operational programmes raises the work load owing to the greater demands. Thus, single-fund programming requires greater coordination to ensure programmes complement each other, and to optimize the effectiveness of programme implementation (Kaiser 2008). The previous evaluation of the OP ESF for Galicia for the previous period has identified some of the difficulties encountered in terms of coordination, and proposed measures such as raising employment and developing the skills of the labor force, and simplifying procedures (Quasar 2003). "The structure is just too complex and hierarchical and works through formal mechanisms that are interwound with other informal unregulated ones" (interview 26 and 27). "This shows you the influence of networks of clientelism that may have been slightly perturbed by the shared management model applied in Europe, but nonetheless continue to sway local policy on the implementation of EU funds" (interview 26). 
The ESF as a generator and innovator of active employment policies

On the whole, local actors readily acknowledge the contributions of the SF in general, and in particular the ESF, in the development of the Province of Ourense, and the Autonomous Community of Galicia. Though local entities recognized funding had positive outcomes in terms of vocational training, counselling for job seekers, grants for fostering employment, and in raising gender equality at work, it was felt that funding had had little impact in reducing unemployment. Thus, the general view was that 'European funding' had broadened the scope of vocational training, and had promoted employment by providing grants to small and medium-sized enterprises or to help entrepreneurs to setup businesses (Interviews $4,11,13)$. Funding had also expanded Research and Technological Development (RTD) projects, and had extended the use of information communication technology among employed and unemployed workers, "an achievement that would have been impossible without the ESF" (Interview 9). Thus, the evaluation by the local agents from Ourense coincided with the observations of Verschraegen in the three provinces of Belgium $(2011,59)$ i.e., the ESF had stimulated technological innovation, and active labor market policies. Moreover, ESF stimulated local employment and raised the quality of life of citizens i.e., "it helps the inhabitants in the area of the project" (Interview 1), and "improves the living standards of the inhabitants" (Interview 2).

\section{The unfulfilled expectations of ESF in terms of local implementation}

The resentment regarding 'unfulfilled expectations' in the implementation and application of European funding in the provincial scenario appears to be widespread. The comments of local agents illustrated well their misgivings on two counts. First, the relations between autonomous and central government were perceived as excessively institutionalized i.e., hardly flexible and open to the proactive participation of local agents. Moreover, local actors expressed their disappointment with the outcomes of policies that were inadequately funded, and failed to address the needs of the local population.

In terms of the first grievance i.e., the participation of local agents in European policies, interviewees described the design of EU projects, and the management and implementation of procedures as being based on cooperation, but a high degree of dissatisfaction was detected in what was described as a lack of involvement of local actors in the design of structural policies. This "lack of consultation" with local actors in the development of European projects (Interview 6 and 7) was particularly evident during the programming and design phases, and was the main criticism concerning ESF: "we demand more participation" (Interview 3), "it cannot be implemented without the greater participation of the stakeholders" (Interview 5), "the role of local institutions should be strengthened; if we are the beneficiaries of European policies, we should have greater participation" (Interview 4). The 
lack of participation was also a bone of contention for other social organizations and interest groups. Thus, the actual changes in the relations among central government, and subnational and supranational actors arising from the processes of EU structural policy implementation were overestimated. Among local actors there was an overt feeling they had little or no influence on the regional decisionmaking process, which was reflected in their aspirations: "policy design should be bottom-up and not top-down as it is now", "territorial entities should be taken into account more than they are" (Interview 9).

It is hardly surprising that one of the most frequent recommendations was to include local actors "in the model of aid management and decision-making as to whom and how the funds are applied" (Interview 5). Likewise, the Autonomous Government of Galicia itself has readily admitted in the White Paper of the Committee of the Regions on multi-level governance that 'the voice of regional and local entities remains to be heard with sufficient force, and its points of view are insufficiently accounted for in the design of EU policies and legislation' (Xunta De Galicia 2011a, 2). The feedback from agents local was almost restricted to drafting progress reports to higher authorities. Notwithstanding, local actors had the hands-on responsibility for implementing on the ground the actions and operations outlined in the projects, working directly with the final beneficiaries.

As for the second grievance i.e., the lack of knowledge regarding the full implications of local problems and issues, local actors felt that the "absent participation" of local authorities in the design and programming of the ESF led to "voids" or "neglected areas" of European policy. An unfair distribution of resources between coastal and inland areas had favored the former in detriment of the latter that remain "neglect rural areas" (Interview 24), and the ESF is perceived as widening rather than bridging this regional gap through its procedures for applying for funding and grants.

Overall, interviewees were disappointed with the achievements in the socioeconomic development of Galicia following the implementation of EU funds. In other words, over 75 per cent of respondents believed funding had contributed to a certain degree of socioeconomic development in Galicia; however, the same number of respondents were hardly satisfied with the outcomes considering the amount of resources invested. In terms of the provincial development of Ourense, respondents stated the ESF had had a scarce impact or none at all on structural problems e.g., the exodus from rural areas, the lack of employment opportunities, and other demographic problems derived from living in sparsely populated rural areas such as the risk of social exclusion, or deficient public transport. A further example was promoting tourism which was identified by many respondents as a priority for European funding. Thus, the restoration of historic towns or the rehabilitation of rural properties for commercial purposes such as rural holiday homes were described as "small business projects of entrepreneurs that had not affected significantly the population as a whole" (Interview 15). 
Hence, the impact of ESF implementation on the socioeconomic development of the Province of Ourense and in the wider Autonomous Community of Galicia was perceived by respondents as poor and/or disappointing: "had little impact and poor participation considering the initial expectations and the resources available" (Interview 6) or "the objectives were well programmed, but the resources were inefficiently used" (Interview 7).

European programmes and central government guidelines imposed on the distant periphery fail to fully appreciate the circumstances and structural dimensions of local issues. They cannot pinpoint or assess in depth each sector, "territorial circumstances are ignored when programmes are designed," (Interview 1), and broad, general selection criteria and procedures are discriminatory against sectors, areas or groups that are at high risk of social exclusion: "The selection criteria are clearly restrictive for some and favorable to others" (Interview 7), "competition is a requirement that tends to favor more developed areas" (Interview 9): "it serves the general population, rather than specific groups" (Interview 10).

Thus, EU policies were rebuked for overlooking structural weaknesses in the provincial and autonomous socio-economic environment e.g., farm bankruptcies, the lack of employment opportunities in rural areas, the absence of policies for maintaining rural populations, and the territorial disparity between densely and sparsely populated areas are just some of the issues that characterize local reality, but are "invisible" during the design and programming of ESF: "It is difficult for this territorial reality to fit in with the programmes" (Interview 9). The implications of these local issues are overwhelming and local actors complain that EU resources are insufficient: "You work for 7 thousand people yet you only receive money for 85 " (Interview 12), a grievance that is only further exasperated by the feeling that funding is badly distributed.

On a similar note, the evaluations of ESF have underscored the vital role of cooperation among local corporations and associations, and that the territorial proximity and the shared social reality of local agents with the target population had raised the awareness and sensitivity of the Galician population in relation to EU funding (Xunta De Galicia 2011b, 53). Local administrations perform a vital role in ESF by mobilizing local actors who foster debate on key issues of European policy which strengthens the identity of European citizenship. Moreover, handing down power to local actors promotes democratic legitimacy and representativeness, and reinforces the process of European integration.

\section{Conclusion}

EU cohesion policy is in the words of Hooghe (1999) 'the flagship of regulated capitalism'. In these times of economic crisis where the market dictates politics, cohesion is a reminder of a political and social commitment, 'the basic idea of the European Union entails the concept of solidarity, i.e. a common interest in 
the well-being of all countries, regions and, ultimately, of all individuals who belong to the Union' (Cal 2005, 51). In recent years, cohesion policy in terms of ESF in Ourense has witnessed progressive decentralization, increased funding, and multi-annual programming which have proved to be vital for improving the efficacy of local public administration in delivering and implementing ESF development strategies, and in strengthening the Europeanization of subnational public administration.

This analysis of ESF implementation has highlighted the transformation of the Galician model of public administration and its convergence with the model of multi-level governance. Nevertheless, multilevel governance of ESF appears to be a formal or aspirational type of Europeanization that is expounded by Europeans institutions and corroborated by the literature, but perceived as being of little substance and insufficient by the final beneficiaries. This case study on the local implementation of ESF has revealed that the institutional building process between local actors rested on ESF implementation based on the dominance of national government and autonomous institutions. This would explain the disappointment felt by local agents regarding their participation in EU structural policy, and underlines the need for fostering 'bottom-up' approaches and shared management to enable target populations in determining the future of their own territory. This approach would ensure the participation of the wider population and local agents in territorial development in accordance with their own aspirations, expectations, and projects. However, the 'bottom-up' approach is neither systematically applied (nor applicable) everywhere and under all circumstance i.e., participation is more often than not a trend or an aspiration rather than a real-life working condition. Notwithstanding, EU institutions are committed to the principle of joint management, and strive to ensure the population and local agents take center stage in the process of rural development.

Finally, owing to the deficient participation of local actors, and in relation to the initial hypothesis of this study that insufficient participation of local actors would lead subsequently to deficient operationalization of ESF, most local agents believed ESF interventions lacked flexibility and failed to adjust to meet the specific local needs of populations i.e., resources were inadequately allocated, and many local issues remained neglected under ESF. The procedure for the joint management of ESF has been restricted to the central government's devolution of power to the autonomous communities who in turn are unwilling to abdicate the channeling of European funds to local authorities.

Local agents have to overcome surmounting obstacles in municipal management given the lack of resources that undermines investment in new employment projects. As the economic crisis spreads throughout the economy, the priorities of ESF become essential tools, not only for speeding up economic recovery in Europe, but also in addressing issues that are relevant to each specific local population in order to counteract the growing disillusionment with Europe 
and its institutions that are perceived as inefficient in responding to vital problems and issues of the current economic crisis.

\section{Bibliographic references}

ARMESTO PINA, José Francisco (2008). El impacto de la política regional comunitaria en Galicia. Una panorámica. Revista Galega de Economía 17: 1-18.

BACHE, Ian (2007). Cohesion Policy. In: P. Graziano and M. Vink (eds). Europeanization: New Research Agenda. Basingstoke: Palgrave MacMillan, p. 239-252.

BACHE, Ian and JONES, Robert (2000). Has EU regional policy empowered the regions? A study of Spain and the United Kingdom. Regional and Federal Studies 10: 1-20.

BATTERBURY, Sarah (2002). Evaluating Policy Implementation: The European Union's Small and Medium Sized Enterprise Policies in Galicia and Sardinia. Regional Studies 36 (8): 861-876.

BULMER, Simon (1994). The Governance of the European Union: a New Institutionalist Approach. Journal of Public Policy 13 (4): 351-380.

CAL, Vasco (2005). Integración económica y cohesión social: la experiencia de la Unión Europea. In: J.L. Machinea and A. Uthoff (eds). Integración económica y cohesión social: lecciones aprendidas y perspectivas. Santiago de Chile: Publicación de las Naciones Unidas, p. 51-60.

CALVO, Ricardo and LERMA, Ignacio (2008). Desarrollo local: ¿̨clientelismo subvencionado? conclusiones críticas al modelo actual. Acciones e investigaciones sociales 25: 5-22.

CENSIS (1991). Construir Europa. La Europa de lo social. Madrid: Centro de Estudios Ramón Areces.

CONSEJO ECONÓMICO Y SOCIAL (2013). Informe sobre el acuerdo de asociación de España en el marco de la política de cohesión 2014-2020. Madrid: Consejo Económico y Social.

CLOSA, Carlos (2004). El valor de las instituciones: mandato y auto-mandato en el proceso de la Convención. Cuadernos Europeos de Deusto 30: 39-56.

DEYON, Paul (1997). Régionalismes et régions dans l'Europe des quince. Toulouse: Editions locales de France.

ESPASA, Manuel (2008). Las nuevas perspectivas financieras de la Unión Europea: implicaciones y consecuencias para Galicia. Revista Galega de Economia 17: 1-24.

EUROPEAN PARLIAMENT (2006). Regulation (EC) No 1081/2006 on the European Social Fund and Repealing Regulation.

. (2014). Report on EU Member States preparedness to an effective and timely start of the new Cohesion Policy Programming period. (2013/2095 INI).

FARGION, Valeria; MORLINO Leonardo and PROFETI, Stefania (2006). Europeanisation and territorial representation in Italy. West European Politics 29 (4): 757-833.

FAYOLLE, Jacky and LECUYER, Anne (2000). Regional Growth, National Membership and European Structural Funds: An Empirical Appraisal. Revue de l'OFCE 0 (73): 165-196.

FERRY, Martin and MCMASTER, Irene (2005). Implementing structural funds in polish and Czech regions: convergence, variation, empowerment?. Regional \& Federal Studies 15 (1): 19-39. 
FOTEA, Ioan; LAZAR, Mariana; SASS, Carmen; and VADUVA Sebastian (2011). Improving the absorbtion of european funds by public administration: case study romanian city-halls. International Journal Of Business and Management Studies 3 (2): 307-315.

GONZÁLEZ, José Luis, and BENEDICTO, Miguel Angel (2006). La mayor operación de solidaridad de la historia. Crónica de la política regional de la UE en España. Luxembourg: Office for Official Publications of the European Communities.

HELD, David (1995). Democracy and The Global Order: From the Modern State to Cosmopolitan Governance. Cambridge: Polity Press.

HOOGHE, Liesbet (1999), La política de cohesión de la Unión Europea y los modelos enfrentados de capitalismo europeo. In: I. Llamazares and F. Reinares (eds). Aspectos politicos y sociales de la integración europea. Valencia: Tirant lo Blanch, p. 201-224.

HOOGUE, Liesbet; and MARKS, Gary (2001) Multi-Level Governance and European Integration. Lanham: Rowman \& Littlefield.

KAISER MOREIRAS, José Luis (2008). La política regional europea 2007-2013: Principales novedades con respecto a 2000-2006. Presupuesto y Gasto Público 52: 129-142.

KEATING, Michael (2008). A quarter century of the Europe of the Regions. Regional and Federal Studies 18 (5): 629-635.

KEATING, Michael and JONES, Barry, Eds. (1985). Regions in the European Community. Oxford: Clarendon.

KOOIMAN, Jan (2003). Governing as Governance. London: Sage.

LAFFAN, Brigid (1983). Policy Implementation in the European Community: The European Social Fund as a Case study. Journal of Common Market Studies XXI (4): 379-408.

LE GALES, Patrick (2003). Le retour des villes européennes. Sociétés urbaines, mondialisation, gouvernement et gouvernance. Paris: Presses de la Fondation Nationale des Sciences Politiques.

LEIBER, Sabine (2005). Implementation of EU social policy in Poland: is there a different "Eastern World of Compliance"?. 9a Biennial International Conference of the European Unions Studies Association. Austin. March 31-April 2.

LÓPEZ-SANTANA, Mariely (2009). Having a Say and Acting: Assessing the effectiveness of the European Employment Strategy as an intra-governmental coordinative instrument. In: S. Kröger (ed.). What we have learnt: Advances, pitfalls and remaining questions in OMC research. European Integration Online Papers 1: 13-15, [http://eiop.or.at/eiop/texte/2009-015a. htm]. Avaliable: 4/03/2014.

LÓPEZ VISO, Mónica (2004). El desarrollo de la política social europea en Galicia. Revista De Estudios Regionales 71: 157-176.

. (2010). The social dimension of European cohesion policy in a 27-state Europe: an analysis of the European Social Fund. European Journal of Social Work 13: 1369-1457.

MÁIZ, Ramón (1994). Estructura y acción: elementos para el análisis micropolítico del clientelismo. Revista Internacional de Sociología 8-9: 189-215.

MARKS, Gary; SCHARPF, Fritz W.; SCHMITTER, Philip C., and STREECK, Wolfgang (1996). Governance in the European Union. London: Sage. 
MAYNTZ, Renate (1998). New challenges to governance theory. Jean Monnet Chair Paper. RSC 98/50, [http://cadmus.eui.eu/handle/1814/23653]. Avaliable: 02/07/2013.

METCALFE, Les (1995). La Comisión Europea como una organización-red. Gestión y Análisis de Políticas Públicas 4: 25-36.

MORATA, Francesc (2007). La europeización del Estado autonómico. In: F. Morata and G. Mateo (eds.). España en Europa-Europa en España (1986-2006). Barcelona: CIDOB, p. 149-178.

MOUFFE, Chantal (2003). La paradoja democrática. Barcelona: Gedisa.

NOGUEIRA ROMÁN, Camilo (2008). Galicia en la Unión Europea. Una economía emergente. Revista Galega de Economía 17: 1-18.

ORDÓÑEZ SOLÍS, David (2011). La gestión de los fondos europeos. Revista de derecho de la Unión Europea 20: 117-149.

PARDO GARCÍA, Isabel (2000). La reforma de los fondos estructurales y la cohesión económica y social. Boletín económico del ICE (Información Comercial Española) 2657: 49-60.

PETIT DE GABRIEL, Eulalia W. (2010). Gobernanza multinivel y gestión de los fondos estructurales en Andalucía: ¿Realidad o quimera?. Sevilla: Fundación Centro de Estudios Andaluces.

PHARR, Susan and PUTNAM, Robert (2000). Dissaffected democracies What's Troubling the Trilateral Countries. Princenton: Princeton University Press.

QUASAR (2003). Evaluación intermedia del Programa Operativo Integrado de Galicia 2000-2006 (FEDER, FSE, FEOGA-O). Documento Final. Madrid: Xunta de Galicia-Quasar.

RHODES, Rod A.W. (1997). Understanding Governance: policy Networks, Governance Reflexivity and Accountability. Buckingham: Open University Press.

RODRÍGUEZ-POSE, Andrés and FRATESI, Ugo (2004). Between Development and Social Policies: The Impact of European Structural Funds in Objective 1 Regions. Regional Studies 38 (1): $97-113$.

SÁNCHEZ SALGADO, Rosa (2013). From "talking the talk" to "walking the walk": Implementing the EU guidelines on employment through the European Social Fund. European Integration online Papers 17 (2), [http://eiop.or.at/eiop/texte/2013-002a.htm]. Avaliable: 04/03/2013.

SMITH, Andy (1997). Studying Multi-Level Governance. Examples from french translations of the Structural Funds. Public Administration 75 (Winter): 711-729.

SOSVILLA-RIVERO, Simón and HERCE, José A. (2004). La politica de cohesión europea y la economía española: evaluación y prospectiva. Madrid: Real Instituto Elcano.

STOKER, Gerry (1998). El buen gobierno como teoría: cinco propuestas. Revista Internacional de Ciencias Sociales 155: 3-35.

Ed. (2000). The New Politics of British Local Governance. Londres: Mc-Millan.

TÖMMEL, Ian (2004). Las transformaciones de la gobernanza: La estrategia de la Comisión Europea a favor de la Europa de las regiones. In: F. Morata (ed.). Gobernanza multinivel en la UE. Valencia: Tirant lo Blanch, p. 87-120. 
VANHERCKE, Bart; VANDERBORGHT, Yannick; and VERSCHRAEGEN, Gert (2011). L'Europe sociale en Belgique: emploi et inclusion sociale au prisme de L'européanisation. Revue belge de sécurité sociale 4: 745-774.

VERSCHRAEGEN, Gert; VANHERCKE, Bart; and VERPOORTEN, Rika (2011). The European Social Fund and domestic activation policies: Europeanization mechanisms. Journal of European Social Policy 21: 55-72.

XUNTA DE GALICIA (2007). Avaliación ex ante do programa operativo FSE de Galicia 2007-2013. Santiago: Consellería de Facenda.

. (2008a). Programa Operativo Fondo Social Europeo Galicia 2007-2013. Santiago: Consellería de Facenda.

. (2008b). Marco Estratéxico de Converxencia Económica de Galicia 2007-2013. Santiago: Consellería de Facenda.

- (2008c). Marco Estratéxico de Converxencia Económica de Galicia 2007-2013. Revista Galega de Economía 17: 7-26.

. (2008d). Plan de Comunicación del Programa Operativo del FSE de Galicia 2007-2013. Santiago: Consellería de Facenda.

. (2011a). Aportaciones de la Xunta de Galicia al Libro Blanco sobre Gobernanza Multinivel. Santiago: Xunta de Galicia.

(2011b). Evaluación del Plan de Comunicación del PO FSE Galicia 2007-2013. Santiago: Xunta de Galicia.

Submitted September 22, 2014

Accepted November 18, 2014

\begin{abstract}
Implementing multi-level governance has been a key priority in EU cohesion policy. This study assesses the perceived achievements and shortcomings in implementing European Social Fund by analyzing the deficits and weaknesses as well as the poor participation of local agents who are in direct contact with the beneficiaries in order to design and implement this fund, which is the main financial instrument of EU social policy.
\end{abstract}

Keywords: local agents; multi-level governance; social cohesion policy.

\title{
Resumo
}

A implementação da governança multinível tem sido uma prioridade na política de coesão da EU. Este estudo avalia as conquistas e as fraquezas da implementação do Fundo Social Europeu analisando as escassezes e debilidades como a pobre participação dos agentes locais que estão em contato direto com os beneficiários para elaborar e implementar esse fundo, o qual é um instrumento financeiro principal na política social europeia.

Palavras-chave: agentes locais; governança multinível, política de coesão social. 